\title{
Surface Expression of Fcy Receptor III (CD16) on Chemoattractant-stimulated Neutrophils Is Determined by Both Surface Shedding and Translocation from Intracellular Storage Compartments
}

Michael F. Tosi and Harriet Zakem

Department of Pediatrics, Case Western Reserve University School of Medicine, Cleveland, Ohio 44106

\begin{abstract}
Stimulation of neutrophils (PMN) with chemoattractants markedly increases surface expression of several membrane proteins, including the complement receptors, $\mathrm{CR1}$ and $\mathrm{CR3}$, by translocation from intracellular storage compartments to the cell surface. When we stimulated freshly-isolated PMN with FMLP, we observed little net change in surface Fcy receptor (R) III expression. However, if elastase was first used to cleave most (85-90\%) of the Fc $\gamma$ R III from the PMN surface, subsequent treatment with FMLP induced a rapid renewal of surface Fc $\gamma$ R III, achieving levels of $\sim 70 \%$ of that originally present on the cell surface after $15 \mathrm{~min}$, suggesting translocation of intracellular receptors. This was confirmed by demonstrating concomitant depletion of $>80 \%$ of the intracellular Fe $\gamma$ R III. Studies of density gradient fractions of $\mathrm{N}_{2}$-cavitated PMN indicated at least two distinct intracellular membrane fractions that contain Fc $\gamma$ R III. Shedding of Fe $\gamma$ R III induced by FMLP was about half-maximal by $15 \mathrm{~min}$ and nearly complete by $60 \mathrm{~min}$. Stoichiometric assessment of FMLP-induced changes in PMN surface and intracellular Fc $\gamma$ R III showed a marked depletion in intracellular Fc $\gamma$ R III, little net change in surface Fc $\gamma$ R III, and a large overall loss of total cell Fer $R$ III that could be attributed to shedding. We conclude that stimulation by chemoattractants causes a rapid translocation of intracellular Fc $\gamma$ R III to the PMN surface that is roughly balanced by the concomitant FMLP-induced shedding of this receptor. (J. Clin. Invest. 1992.90:462-470.) Key words: Fc $\gamma$ receptor III • neutrophils • receptor shedding • translocation
\end{abstract}

\section{Introduction}

Exposure of neutrophils (PMN) to chemoattractants in vitro or in vivo causes marked increases in the surface expression of several membrane-associated proteins by inducing rapid translocation of preformed intracellular storage pools to the PMN surface $(1,2)$. These include the $C 3 b$ receptor $(C R 1),{ }^{1}$ the

Address reprint requests to Dr. Tosi, Department of Pediatrics, Case Western Reserve University, 2101 Adelbert Road, Cleveland, OH 44106.

Received for publication 29 August 1990 and in revised form 16 March 1992.

1. Abbreviations used in this paper: $\mathrm{CR} 1$ and $\mathrm{CR} 3, \mathrm{C} 3 \mathrm{~b}$ and $\mathrm{C} 3 \mathrm{bi}$ receptors; PIPLC, phosphatidyl inositol-specific phospholipase C; $R$, receptor.

J. Clin. Invest.

(c) The American Society for Clinical Investigation, Inc.

0021-9738/92/08/0462/09 \$2.00

Volume 90, August 1992, 462-470
C3bi receptor (CR3), receptors for chemoattractant peptides, decay accelerating factor, and the cytochrome of the NADPH oxidase complex (1-5). In contrast, surface expression of $\mathrm{Fc} \gamma$ receptors $(R)$ is relatively stable after stimulation of PMN with chemoattractants and other stimuli that have been shown to induce six- to eightfold increases in surface expression of other membrane proteins $(1,2,6)$.

Two recently published observations caused us to reevaluate the effects of chemoattractant stimulation of PMN on expression and movement of Fc $\gamma$ R III in these cells. First, Turner et al. (7) found that the Fc $\gamma$ R III on the PMN surface constituted less than one-half of the total cellular content of this receptor and, thus, that PMN contained a substantial intracellular pool of $F c \gamma$ R III. This was confirmed by Jost et al. (8), who demonstrated intracellular Fc $\gamma$ R III in PMN by immunoelectron microscopy. Second, Huizinga et al. (9) showed that activation of PMN with FMLP caused shedding of Fc $\gamma$ R III from the cell surface. Thus, we proposed that the relative stability of Fc $\gamma$ R III on the surface of PMN during chemoattractant stimulation represented translocation of intracellular Fc $\gamma$ R III to the PMN surface that roughly matched the loss of surface Fc $\gamma$ R III receptors caused by shedding. We reasoned that, if most of the surface Fc $\gamma$ R III on the surface of resting PMN could be removed before FMLP stimulation, then the appearance of new Fc $\gamma$ R III on the cell surface would be more readily detectable. Tosi and Berger (10) recently documented that $\mathrm{Fc} \gamma$ $\mathrm{R}$ III on PMN is sensitive to cleavage by elastase. Because Fc $\gamma$ $\mathrm{R}$ III on PMN is anchored in the plasma membrane by a glycolipid anchor, it can also be cleaved by phosphatidyl inositolspecific phospholipase C (PIPLC) (9). By first using elastase or PIPLC to cleave $85-90 \%$ of the Fc $\gamma$ R III from the surface of resting $P M N$, we were able to observe large increases in surface expression of $\mathrm{Fc} \gamma \mathrm{R}$ III upon stimulation of PMN with FMLP, with concomitant depletion of intracellular Fc $\gamma$ R III. Additional studies comparing the time course and dose response of FMLP-induced shedding of Fc $\gamma$ R III with those for its translocation provided further insight about the regulation of surface expression of $\mathrm{Fc} \gamma \mathrm{R}$ III during chemoattractant stimulation of these cells.

\section{Methods}

Reagents. Neutrophil elastase $(875 \mathrm{U} / \mathrm{mg}$ ) was purchased from Elastin Products, Pacific, MO. FMLP, ionomycin, PMSF and cycloheximide were purchased from Sigma Chemical Co., St. Louis, MO. Monoclonal antibody against Fc $\gamma$ R III (CD16) from hybridoma clone 3G8 was kindly provided by Dr. Jay Unkeless, Mount Sinai Medical Center, New York. Monoclonal antibody against Fc $\gamma$ R II (CD32) was the gift of Drs. Michael Fanger and Paul Guyre, Hanover, NH. Monoclonal antibody (IgG1) against casein was provided by Dr. Charlotte Kaetzel, Cleveland, OH. PIPLC from Bacillus cereus was purchased from Boehringer Mannheim Biochemicals, Indianapolis, IN. 
Purification and preparation of neutrophils. PMN were purified from the peripheral blood of healthy adults by sedimentation with dextran and centrifugation of the resulting leukocyte-rich plasma over a Ficoll-Hypaque cushion as previously described (11), followed by hypotonic lysis of residual red blood cells. The purity and viability of these PMN preparations were consistently $>95 \%$. For experiments that required removal of $\mathrm{Fc} \gamma \mathrm{R}$ III from the PMN surface before stimulation, the cells were incubated at $37^{\circ} \mathrm{C}$ for $30 \mathrm{~min}$ with $30 \mu \mathrm{g} / \mathrm{ml}$ of neutrophil elastase or for $60 \mathrm{~min}$ with $0.1 \mathrm{U} / \mathrm{ml} \mathrm{PIPLC}$. After washing to remove the enzyme, treated or control PMN were incubated with a range of agents including FMLP, ionomycin, EDTA, EGTA, and/or cycloheximide for durations up to $120 \mathrm{~min}$. PMN supernatants were treated with $1 \mathrm{mM}$ PMSF immediately after recovery and then stored on ice until assayed for released $\mathrm{Fc} \gamma \mathrm{R}$ III.

Analysis of surface $F c \gamma R$ III expression by immunofluorescence flow cytometry. After various treatments, PMN $\left(1 \times 10^{6}\right)$ were incubated for $30 \mathrm{~min}$ at $4^{\circ} \mathrm{C}$ with an excess of monoclonal antibody (3G8) against Fc $\gamma$ R III, or an irrelevant isotype-matched control antibody. Cells were washed three times in Dulbecco's PBS (Gibco Laboratories, Grand Island, NY) and then incubated with FITC-conjugated goat $\mathrm{F}\left(\mathrm{ab}^{\prime}\right)_{2}$ anti-mouse IgG (Cappel Laboratories, West Chester, PA) for an additional $30 \mathrm{~min}$ at $4^{\circ} \mathrm{C}$. After further washing and resuspension in PBS, cells were analyzed in a FACS Analyzer (Becton, Dickinson \& Co., Mountain View, CA), and the mean fluorescence of 5,000 cells was used as a measurement of surface expression of $\mathrm{Fc} \gamma \mathrm{R}$ III, as previously described (10).

Preparation of fixed, permeabilized PMN for immunofluorescent staining. Fixation and permeabilization of PMN for direct fluorescent staining of intracellular Fc $\gamma$ R III was accomplished by using a modification of a method previously described (7). Briefly, PMN recovered after various treatments were first fixed for $2 \mathrm{~h}$ with cold $2 \%$ paraformaldehyde. Aliquots of these fixed PMN were then permeabilized by suspending them in $0.1 \%$ ovalbumin/PBS/0.1 M glycine with $0.04 \%$ saponin for all remaining steps in indirect immunofluorescent staining, including 30-min incubation at room temperature with the anti-Fc $\gamma$ R III MAb $3 \mathrm{G8}$ or a mouse IgG1 control MAb, and staining with a FITCconjugated $\mathrm{F}\left(\mathrm{ab}^{\prime}\right)_{2}$ goat anti-mouse IgG second antibody. After three additional washes by centrifugation in the ovalbumin/PBS/saponin, cells were washed once and resuspended in PBS before flow cytometric analysis and fluorescence microscopy. Parallel aliquots of fixed PMN were treated identically but without saponin for non-permeabilized controls.

Cavitation and subcellular fractionation of PMN. PMN were subjected to nitrogen cavitation and discontinuous Percoll density gradient fractionation as described by Borregaard and Tauber (12). Nuclei and unbroken cells were removed from the crude PMN cavitate by centrifugation at $500 \mathrm{~g}$ for $10 \mathrm{~min}$ at $4^{\circ} \mathrm{C}$. In $15-\mathrm{ml}$ polycarbonate centrifuge tubes, $5 \mathrm{ml}$ of Percoll, $1.12 \mathrm{~g} / \mathrm{ml}$, was layered under $5 \mathrm{ml}$ of Percoll, $1.050 \mathrm{~g} / \mathrm{ml} ; 3 \mathrm{ml}$ of PMN cavitate was then layered on top of the Percoll gradient and centrifuged for $15 \mathrm{~min}$ at $48,000 \mathrm{~g}$. Fractions (1.0-1.2 ml) were collected from the bottom of the gradient into polypropylene tubes that contained $10 \mu \mathrm{l}$ of $100 \mathrm{mM}$ PMSF and held on ice until analyzed.

Microtiter plate assays of markers for granule and plasma membrane fractions. Alkaline phosphatase in density gradient fractions was assayed by mixing aliquots $(50 \mu \mathrm{l})$ of each fraction with $50 \mu \mathrm{l}$ of a solution of $p$-nitrophenyl phosphate $(1 \mathrm{mg} / \mathrm{ml}$; Sigma Chemical Co.) in wells of a 96-well microtiter plate. After $60 \mathrm{~min}$ at room temperature, the absorbance at $\mathbf{4 1 0} \mathrm{nm}$ was read in an automated microtiter plate reader (Dynatech Laboratories, Inc., Alexandria, VA). After correction for turbidity in some fractions, peak alkaline phosphatase activity was used to identify plasma membrane-containing fractions (12).

Lactoferrin in density gradient fractions was measured using a sandwich ELISA as previously described (13), and peak lactoferrin values were used to identify secondary (specific) granule-containing fractions.

A modification of the method described by Henson et al. (14) was employed to measure myeloperoxidase. Aliquots $(25 \mu \mathrm{l})$ of each gra- dient fraction were added to $100 \mu \mathrm{l}$ of $0.1 \mathrm{M}$ phosphate buffer, $\mathrm{pH} 6.2$, in microtiter wells, followed by $25 \mu \mathrm{l}$ of a freshly prepared mixture of equal volumes of dimethoxybenzidine $(1.25 \mathrm{mg} / \mathrm{ml})$ and $0.1 \% \mathrm{H}_{2} \mathrm{O}_{2}$. After $30 \mathrm{~min}$, absorbance at $460 \mathrm{~nm}$ was recorded. Peak myeloperoxidase activity was taken to indicate the primary (azurophilic) granulecontaining fractions.

Western blot analysis of Fcy $R$ III in PMN fractions and supernatants of stimulated PMN using $M A b 3 G 8$. PMN fractions from the density gradients or activated PMN supernatants described above were subjected to SDS-PAGE by the method of Laemmli (15), using $10 \%$ acrylamide gels under non-reducing conditions. An aliquot of a PMN lysate that had been prepared previously with $0.05 \% \mathrm{NP}-40$ and $1 \mathrm{mM}$ PMSF and stored at $-80^{\circ} \mathrm{C}$ was used as a positive blotting control for Fc $\gamma$ R III. Identically prepared lysates of an airway epithelial cell line, 9HTEo ${ }^{-}$(kindly provided by Dieter Gruenert, San Francisco, CA ) was used as a negative cell control. Electrotransfer of proteins from the gels to nitrocellulose paper was achieved using a Transphor electrophoresis unit, as previously described (Hoefer Scientific Instruments, Inc., San Francisco, CA) (16). The nitrocellulose paper was blocked with 5\% BSA for $60 \mathrm{~min}$, then placed in a Decaprobe multilane staining unit (Hoefer Scientific Instruments, Inc.). Each lane was overlaid with MAb to Fc $\gamma$ R III (3G8) or an isotype-matched (IgG1) control MAb to casein at $\sim 40 \mu \mathrm{g} / \mathrm{ml}$ in $1 \% \mathrm{BSA} / \mathrm{PBS}$ and incubated for $1 \mathrm{~h}$ on a rocker platform at $4^{\circ} \mathrm{C}$. Lanes were then washed three times for $20 \mathrm{~min}$ each with PBS $/ 1 \%$ BSA $/ 0.1 \%$ Tween 20 . Goat anti-mouse IgG $\left.\mathrm{F}(\mathrm{ab})_{2}\right)_{2}$ conjugated to alkaline phosphatase (Southern Biotech, Birmingham, AL) was diluted 1:500 in 1\% BSA and laid over each lane. After incubation for $1 \mathrm{~h}$, as above, the nitrocellulose paper was again washed three times with PBS/BSA/Tween, removed from the Decaprobe unit, rinsed in PBS, and immersed at room temperature in a coupled substrate solution containing nitroblue tetrazolium and 5 bromo-4-chloro-3-indolyl phosphate. The substrate reaction was stopped by rinsing several times in distilled water. The development of a broad band on the nitrocellulose paper in the appropriate molecular mass range (50-70 kD) was taken to indicate the presence and relative amount of $\mathrm{Fc} \gamma \mathrm{R}$ III in a given sample.

Biotinylation of PMN surface proteins. Suspensions of PMN (1.0$1.5 \times 10^{8}$ cells) were incubated with $0.5 \mathrm{mg} / \mathrm{ml}$ sulfo- $N$-hydroxy-succinimidobiotin (Pierce Chemical Co., Rockford, IL) in PBS at pH 8.0 for $1 \mathrm{~h}$ at $4^{\circ} \mathrm{C}(17)$. Cells were then washed three times in PBS, pH 7.4. Surface biotinylation was confirmed by incubating aliquots of labeled and unlabeled cells with a streptavidin-FITC conjugate, then analyzing cells by fluorescence flow cytometry. These surface-biotinylated cells were used to prepare PMN subcellular fractions, as above. Removal of surface-biotinylated proteins from PMN gradient fractions was accomplished by repeated adsorption with excess avidin coupled to agarose beads (Pierce Chemical Co.). Streptavidin blots to detect biotinylated proteins were performed identically to the 3G8 MAb blots described above, except that a 1:5,000 dilution of streptavidin-alkaline phosphatase (Sigma Chemical Co.) was used instead of the antibodies.

Antibody-binding inhibition assay for Fcy $R$ III in PMN supernatants. To assay for soluble Fc $\gamma$ R III based on its ability to inhibit binding of MAb $3 \mathrm{G} 8$ to freshly isolated PMN, we first titrated a single lot of anti-Fc $\gamma$ R III (3G8) hybridoma supernatant to determine the final dilution (1:30) of this supernatant that resulted in $\sim 70 \%$ of the maximal binding to freshly isolated PMN achieved with excess $3 \mathrm{G} 8$, as determined using quantitative immunofluorescence flow cytometry. Aliquots of this standardized lot of 3G8 MAb were diluted 1:15 in activated PMN supernatants and incubated at room temperature for 30 min so that Fc $\gamma$ R III shed from PMN could bind the 3G8 MAb. 50 $\mu$ l of each such mixture was then added to $10^{6}$ freshly isolated PMN in an equal volume of PBS and incubated at $0^{\circ} \mathrm{C}$ for $30 \mathrm{~min}$ so that the remaining free $3 \mathrm{G} 8 \mathrm{MAb}$ would bind to the $\mathrm{Fc} \gamma \mathrm{R}$ III on the fresh cells. These PMN were then stained with a FITC-conjugated goat $F\left(a b^{\prime}\right)_{2}$ anti-mouse IgG and analyzed by fluorescence flow cytometry. The inhibition of $3 \mathrm{G} 8$ binding to the fresh PMN caused by a given PMN supernatant thus reflected the amount of shed Fc $\gamma$ R III that the original supernatant contained. Similarly prepared subsaturating concen- 
trations of MAb to Fc $\gamma$ R II (IV.3) was used as a control in place of anti-Fc $\gamma$ R III (3G8) and confirmed that inhibition of MAb binding was not a generalized effect.

\section{Results}

Chemoattractant-induced up-regulation of surface $F c \gamma R$ III expression on elastase-treated PMN. When $10^{-8} \mathrm{M}$ FMLP was added to normal resting PMN, there was little or no difference in surface expression of $\mathrm{Fc} \gamma \mathrm{R}$ III compared with cells incubated at $37^{\circ} \mathrm{C}$ in buffer alone, as shown in Fig. 1. However, with PMN from which $85-90 \%$ of the surface Fc $\gamma$ R III had been cleaved by pretreatment with elastase, as evidenced by the low values at 0 min, FMLP treatment induced a marked increase in the expression of surface Fc $\gamma$ R III (Fig. 1, $\bullet$ ) to a maximum at $15 \mathrm{~min}$ of $\sim 70 \%$ of that originally present on control PMN. Similar results were obtained when PIPLC was used instead of elastase to remove the Fc $\gamma$ R III (not shown). Little or no increase of Fc $\gamma$ R III expression was seen for elastase-treated PMN if they were held at $37^{\circ} \mathrm{C}$ without FMLP. The optimal concentration of FMLP for up-regulation of surface Fc $\gamma$ R III expression was $10^{-8} \mathrm{M}$ (Fig. $2 A$ ). As shown in Fig. $2 \mathrm{~B}$ the $\mathrm{Ca}^{++}$ionophore, ionomycin $\left(10^{-7} \mathrm{M}\right)$ plus 1.2 $\mathrm{mM} \mathrm{CaCl}_{2}$, caused up-regulation of $\mathrm{Fc} \gamma \mathrm{R}$ III similar to that caused by $10^{-8} \mathrm{M}$ FMLP, suggesting that the induction of a $\mathrm{Ca}^{++}$influx in PMN could produce a similar effect on surface Fc $\gamma$ R III. However, as shown in Fig. $2 C$, when elastase-treated PMN were stimulated with $10^{-8} \mathrm{M}$ FMLP in $\mathrm{Ca}^{++} / \mathrm{Mg}^{++}$-free buffer in the presence of EDTA (or EGTA with $\mathrm{Mg}^{++}$; not shown), the FMLP-induced increase in PMN surface Fc $\gamma$ R III was similar to that observed in the presence of $\mathrm{Ca}^{++}$. Thus, although ionomycin $/ \mathrm{Ca}^{++}$could induce translocation of $\mathrm{Fc} \gamma$ $\mathrm{R}$ III in PMN, the FMLP-induced translocation of Fc $\gamma \mathrm{R}$ III did not require extracellular calcium ion. Cycloheximide pretreatment did not alter the effect of FMLP (not shown), indicating that new protein synthesis was not involved. No treatment listed above had any effect on PMN expression of Fc $\gamma$ R II.

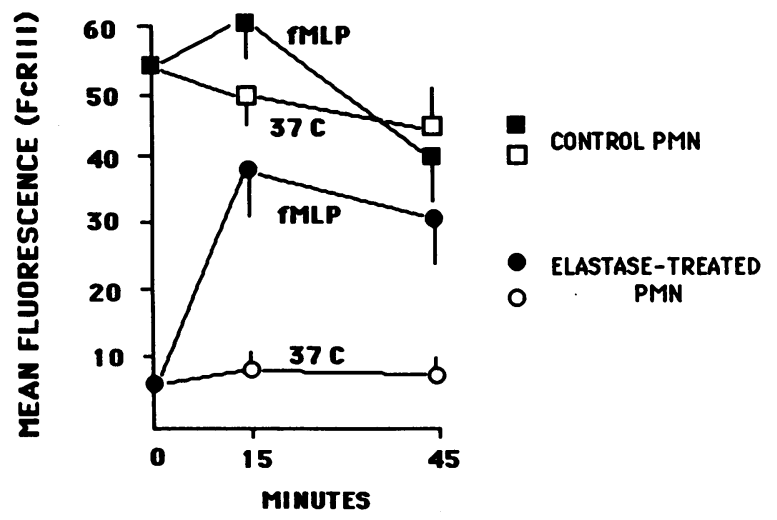

Figure 1. Effect of FMLP treatment on surface expression of Fc $\gamma$ R III for control and elastase-treated PMN. Suspensions of PMN at $10^{7} / \mathrm{ml}$ were incubated at $37^{\circ} \mathrm{C}$ in PBS for $1 \mathrm{~h}$ in the presence or absence of purified neutrophil elastase at $30 \mu \mathrm{g} / \mathrm{ml}$. Cells were washed three times in PBS, incubated with or without $10^{-8} \mathrm{M}$ FMLP, and stained for immunofluorescence flow cytometry with monoclonal antibody to $\mathrm{Fc} \gamma \mathrm{R}$ III. The mean fluorescence of 5,000 cells was determined for each sample. The mean \pm SEM of the values, in fluorescence units, for four or five separate experiments is shown.
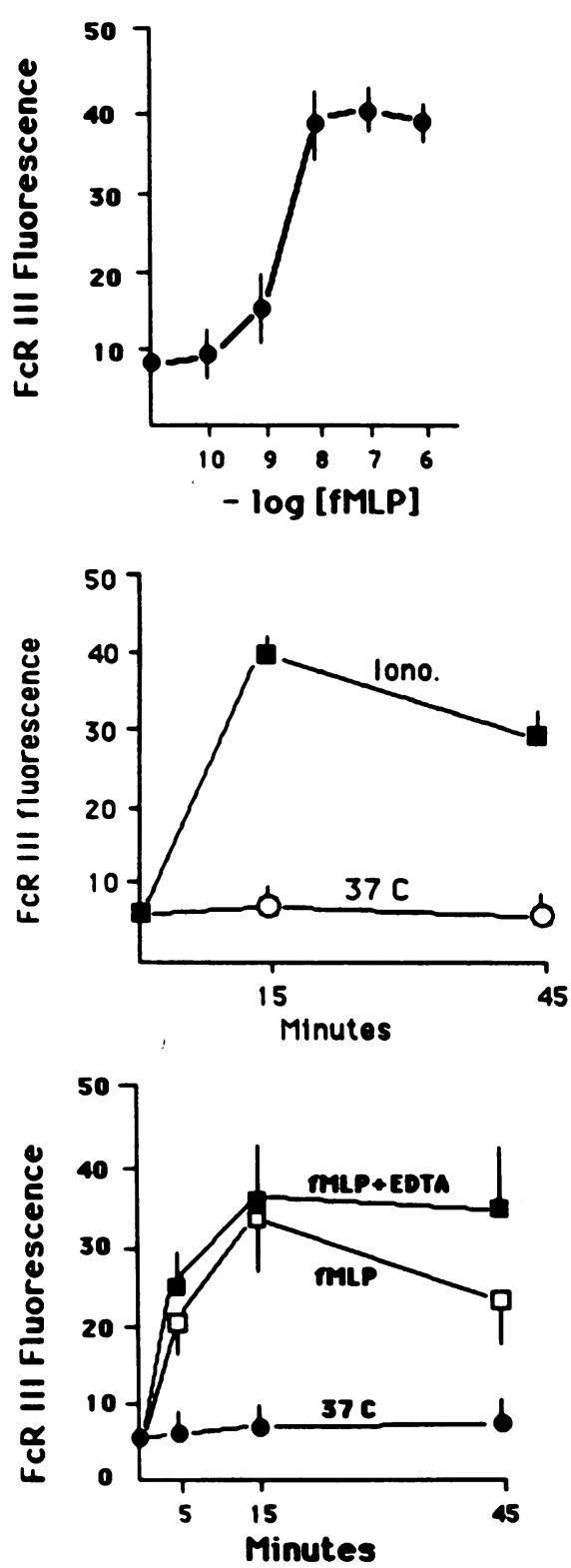

Figure 2. Concentration dependence and divalent cation effects in FMLP-induced up-regulation of Fc $\gamma$ R III surface expression on elastase-treated PMN. PMN were treated with elastase as described for Fig. 1, then $(A)$ incubated for $15 \mathrm{~min}$ at $37^{\circ} \mathrm{C}$ with FMLP at concentrations from $10^{-10}$ to $10^{-6} \mathrm{M} ;(B)$ treated with ionomycin at $10^{-7}$ $\mathrm{M}$ in the presence of $1.2 \mathrm{mM} \mathrm{Ca}^{++}$for the durations indicated; or $(C)$ incubated with $10^{-8} \mathrm{M} \mathrm{FMLP}$ at $37^{\circ} \mathrm{C}$ in our control PBS that contained $1.2 \mathrm{mM} \mathrm{CaCl} / \mathrm{MgCl}$ or with $5 \mathrm{mM}$ EDTA in the absence of added $\mathrm{Ca}^{++}$or $\mathrm{Mg}^{++}$, or at $37^{\circ} \mathrm{C}$ in the absence of FMLP. Cells were stained for surface Fc $\gamma$ R III and analyzed by fluorescence flow cytometry as above. Each value shown is the mean \pm SEM, in fluorescence units, for four separate experiments.

Chemoattractant-induced depletion of intracellular $F c \gamma R$ III in PMN. To confirm the translocation of this receptor from intracellular storage compartments during FMLP stimulation, we performed studies to document the depletion of intracellular Fc $\gamma$ R III. In these experiments, PMN were incubated for 15 min at $0^{\circ} \mathrm{C}$, or at $37^{\circ} \mathrm{C}$ in the presence or absence of $10^{-8} \mathrm{M}$ FMLP. After washing, the cells underwent an additional 30min incubation with elastase and PIPLC to remove $90 \%$ of the 
cell surface $\mathrm{Fc} \gamma \mathrm{R}$ III, so that virtually all the remaining Fc $\gamma \mathrm{R}$ III was intracellular. The PMN were then washed, fixed, permeabilized, and stained for intracellular Fc $\gamma$ R III, as described. The low intensity of background intracellular fluorescence in the fixed, permeabilized PMN stained with the isotype-matched (IgG1) control MAb (Fig. 3, top, panels on left) contrasts sharply with the bright intracellular fluorescence specific for $\mathrm{Fc} \gamma \mathrm{R}$ III in the $0^{\circ} \mathrm{C}$ and $37^{\circ} \mathrm{C}$ PMN. The marked decrease in specific intracellular staining for Fc $\gamma$ R III in the FMLP-treated PMN is readily apparent in the lower right panel, indicating depletion of intracellular Fc $\gamma$ R III. Staining of nonpermeabilized cells for Fc $\gamma$ R III was confined to the cell surface (not shown), and also confirmed that surface Fc $\gamma$ R III accounted for less than half of the total cellular content of this receptor in resting PMN (see Fig. 8). The mean fluorescent intensity of 5,000 cells from each of the six PMN suspensions represented in Fig. 3 (top) was determined by flow cytometry, and the Fc $\gamma \mathrm{R}$ III-specific intracellular fluorescence value for the $37^{\circ} \mathrm{C}$ PMN and the FMLP-treated PMN were expressed as a percentage of that for the $0^{\circ}$ PMN. As shown in Fig. 3 (bottom), these experiments confirmed in a more quantitative way, the depletion of intracellular Fc $\gamma$ R III caused by FMLP treatment of PMN. It should be noted that removal of surface Fc $\gamma$ R III before fixation and permeabilization still leaves a small amount $(\leq 10 \%)$ of surface Fc $\gamma$ R III, so that the flow cytometric measurements of intracellular Fc $\gamma$ R III using this method may be artificially elevated by this amount, for each condition. Further studies were undertaken to determine additional characteristics of the intracellular Fc $\gamma$ R III in PMN.

Distribution of membrane or granule markers and $F c \gamma R$ III in PMN subcellular fractions. To further elucidate characteristics of the intracellular pool(s) of Fc $\gamma$ R III, we examined the migration of this receptor in density gradients of $\mathrm{N}_{2}$-cavitated PMN, as detected by the 3G8 MAb Western blot technique. Because the Western blot technique has not been described previously with MAb 3G8, relevant assay controls are shown in Fig. 4. This assay readily detected Fc $\gamma$ R III in PMN lysates at the correct $M_{\mathrm{r}}$ range and was specific, in that neither the control MAb with PMN, nor $3 G 8$ with control cells resulted in positive blots. The maintenance of nonreducing conditions during SDS-PAGE was essential for successful immunoblotting inasmuch as PMN lysates processed under reducing conditions (2-mercaptoethanol) resulted in no blotting with MAb 3G8. This Western blot assay was used to detect Fc $\gamma$ R III in PMN subcellular fractions, as described below.

Fig. $5 \mathrm{~A}$ shows the distribution of myeloperoxidase, lactoferrin, and alkaline phosphatase in the Percoll density gradient fractions of PMN cavitates, indicating the positions of the azurophilic granules, specific granules, and plasma membrane, respectively, in the gradient, similar to results previously described (18). Fractions decrease in density from fraction 1 to fraction 8. Fractions 9-12 contained mainly cytoplasm and extracellular buffer, and are not shown. Fig. $5 B$ shows by Western blot analysis that $\mathrm{Fc} \gamma \mathrm{R}$ III was prominent in fractions 7 and 8 , which contained the plasma membrane marker peak, and was also present in fractions 4 and 5 , which contained the secondary granule marker peak. Thus, in addition to its expression on the plasma membrane, part of the Fc $\gamma \mathrm{R}$ III in PMN is present in a subcellular membrane fraction with a density similar to that of secondary granules. On inspection, however, there appeared to be less $\mathrm{Fc} \gamma \mathrm{R}$ III in this intracellular fraction than could account for all the intracellular Fc $\gamma$ R III, based on the control
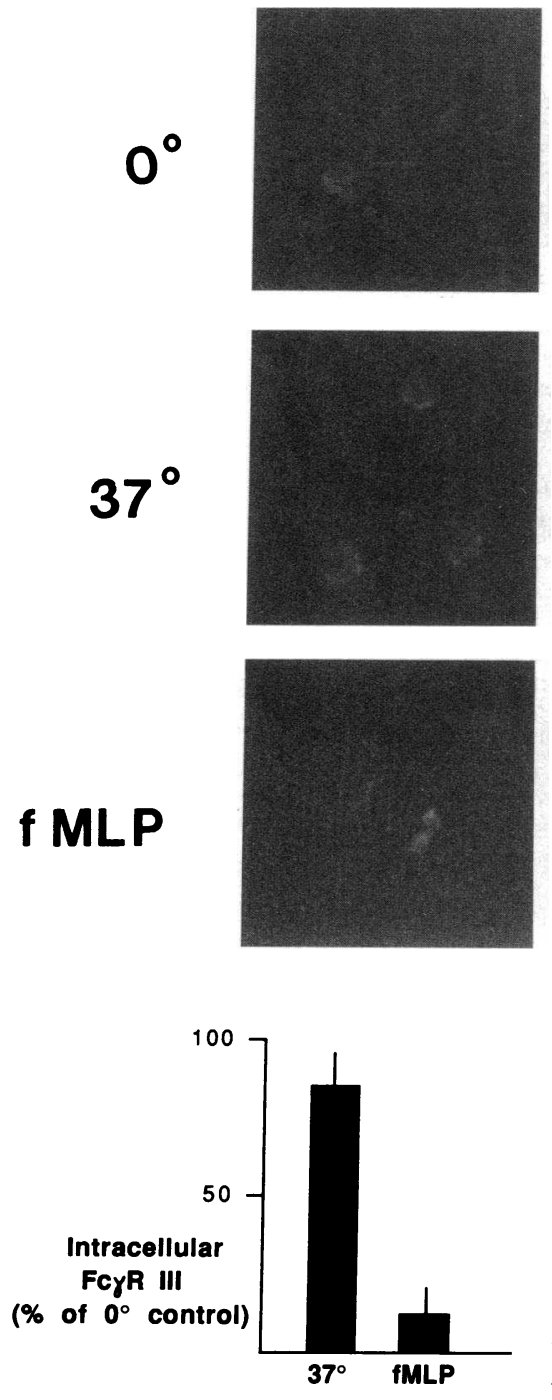

surface Fc $\gamma$ R III, PMN were fixed and permeabilized as described in Methods and stained by indirect immunofluorescence for Fc $\gamma$ R III with MAb 3G8, or with an isotype-matched control MAb of irrelevant specificity. Cells were visualized by fluorescence microscopy and photographed using identical (60-s) exposures. In the upper part of the figure, the three panels on the left show the background staining with the control MAb for $0^{\circ} \mathrm{C}, 37^{\circ} \mathrm{C}$ control, and FMLP-treated cells, respectively. The panels on the right demonstrate the specific intracellular staining for Fc $\gamma$ R III in the corresponding cell suspensions and show the marked depletion of intracellular Fc $\gamma$ R III in cells treated with FMLP. In the lower part of the figure, the composite flow cytometric data from four such experiments ( mean \pm SEM) compare specific intracellular Fc $\gamma$ R III fluorescence as determined by flow cytometry for $37^{\circ} \mathrm{C}$ control vs. FMLP-treated cells, expressed as a percentage of that for the $0^{\circ} \mathrm{C}$ cells, after subtraction of background fluorescence for each condition.

prior observation that over half of total PMN Fc $\gamma$ R III is intracellular (see above and Fig. 8). Because Borregaard et al. $(18,19)$ have described a "latent" intracellular alkaline phosphatase-containing membrane fraction in PMN with a density close to that of plasma membrane, we proposed that some of 


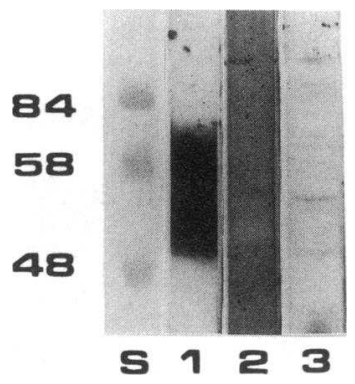

Figure 4. Western blot assay for Fc $\gamma \mathrm{R}$ III with MAb 3G8: assay controls. Detergent lysates of isolated human neutrophils and immortalized human tracheal epithelial cells $\left(9 \mathrm{HTEo}^{-}\right)$ that represented $1-2 \times 10^{4}$ cells and contained equivalent amounts of protein were subjected to SDS-PAGE under nonreducing conditions, transferred to nitrocellulose, and immunoblotted as described in Methods with $3 \mathrm{G} 8$ or an isotype-matched ( $\mathrm{mIgG} 1$ ) control monoclonal antibody of irrelevant specificity at identical concentrations. Lane 1 shows the positive immunoblot of the PMN lysate with 3G8. Lane 2 shows the negative immunoblot of the same PMN lysate with the IgG1 control. Lane 3 shows the negative immunoblot of 9HTEo ${ }^{-}$cells with 3G8. Lane $S$ contains prestained molecular mass standards of 48,58 , and $84 \mathrm{kD}$.

the $\mathrm{Fc} \gamma \mathrm{R}$ III detected in fraction 8 (alkaline phosphatase or "plasma membrane" peak) might represent an additional intracellular pool of Fc $\gamma$ R III that comigrated in the density gradient with the plasma membrane. This was further investigated as described below.

A
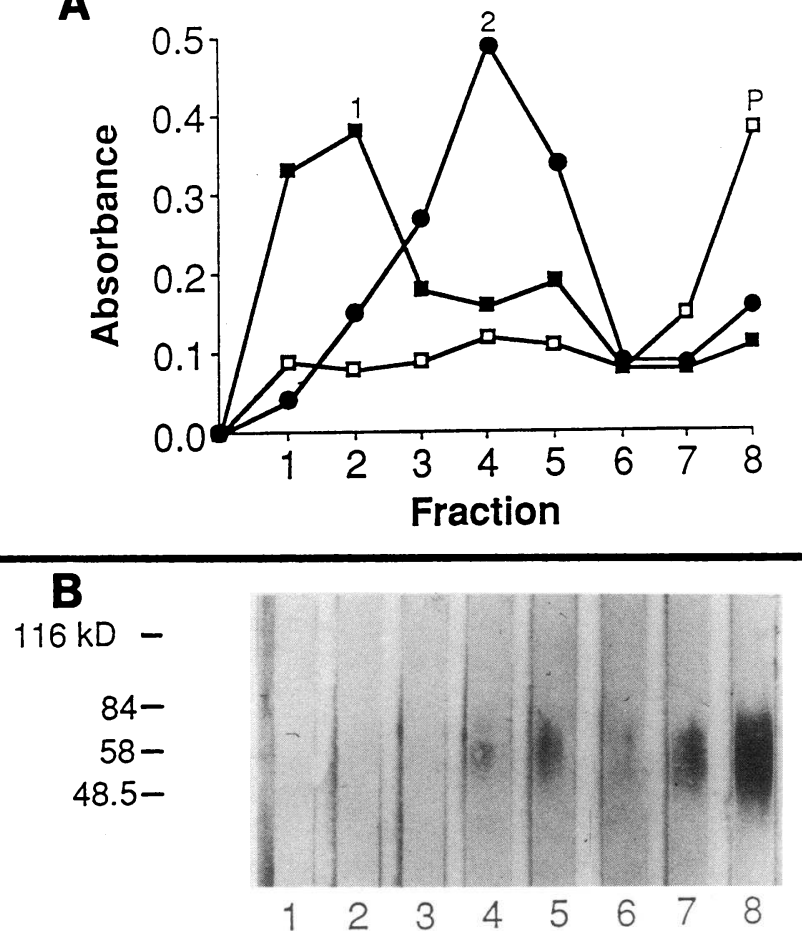

Figure 5. Fc $\gamma$ R III in subcellular fractions. Freshly isolated PMN were disrupted by nitrogen cavitation, and membrane fractions were separated on a discontinuous Percoll gradient, as described. Markers for primary or azurophilic granules ( 1 ; myeloperoxidase), secondary or specific granules ( 2 ; lactoferrin ) and plasma membrane ( $P$; alkaline phosphatase) were assayed as described. As shown in $A$, three distinct membrane populations were delineated based on marker peaks in the gradient fractions. In $B$, western blots for $F c \gamma$ R III in fractions 1-8 show most of the Fc $\gamma$ R III in fraction 8 , with a second peak in fraction 5 . These results were representative of experiments with five different PMN donors.
Part of the Fcr $R$ III in the "plasma membrane-containing fraction" of PMN cavitates represents additional intracellular $F c \gamma R$ III. To address the possibility that some of the intracellular Fc $\gamma$ R III comigrates with plasma membrane in density gradients, as proposed, we surface-labeled PMN with biotin in the cold, and prepared $\mathrm{N}_{2}$ cavitate of PMN, as before. Half of the cavitate was repeatedly adsorbed with solid-phase avidin to remove biotinylated (cell surface) proteins. Density-gradient fractions of both the non-avidin-treated and the avidin-adsorbed cavitates were assessed by Western blot for Fc $\gamma$ R III. Fraction 8 was confirmed for both cavitates as having the largest content of Fc $\gamma$ R III, as well as the alkaline phosphatase peak, as in the previous experiments. When fraction 8 from each condition was subjected to SDS-PAGE and blotted with streptavidin-alkaline phosphatase, it was evident as shown in Fig. 6, that virtually all of the biotinylated (cell surface) proteins had been removed by avidin adsorption (lane $a$ vs. lane $b$, respectively). In contrast, the Western blots for Fc $\gamma$ R III in fraction 8 from the non-avidin-treated vs. the avidin-adsorbed cavitates (lanes $c$ and $d$, respectively) demonstrate that a substantial portion of the Fc $\gamma \mathrm{R}$ III still remained after adsorption by the solid-phase avidin. Thus, some of the Fc $\gamma$ R III that sedimented with the plasma membrane (fraction 8 ) in the density gradients had actually been intracellular (thus not biotinylated), in that it was still present after virtually all biotinylated (cell surface) proteins had been removed. Taken together with Fig. 5, this indicated that the intracellular compartments that contain Fc $\gamma$ R III in PMN exhibit heterogeneous densities, part similar to that of specific granules and part similar to that of plasma membrane.

Chemoattractant-induced shedding of $F c \gamma \quad R$ III from $P M N$ : time and FMLP concentration effects. To study the relationship between the translocation of intracellular Fc $\gamma$ R III and shedding of this receptor from the cell surface in FMLP-

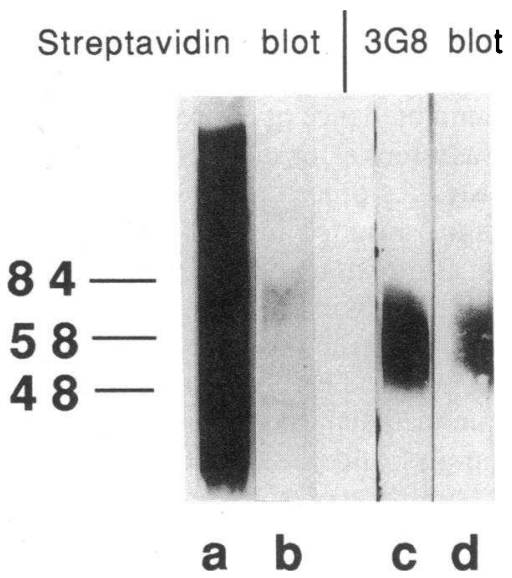

Figure 6. Detection of additional intracellular Fc $\gamma$ R III in plasma membrane-containing PMN fraction by Western blot after removal of biotinylated surface proteins with immobilized avidin. Density gradient fractions of biotinylated PMN were prepared, and the major alkaline phosphatase (or "plasma membrane")-containing fraction was treated repeatedly with excess avidin coupled to agarose beads to remove biotinylated surface proteins. Blots of this fraction before and after avidin treatment were performed with a streptavidin-alkaline phosphatase conjugate to confirm the removal of all biotinylated (surface) proteins (lanes $a$ and $b$, respectively). These were compared with 3G8 Western blots of the same fraction before and after avidin treatment (lanes $c$ and $d$, respectively), to determine the extent of removal of Fc $\gamma$ R III. Although virtually all of the surface biotinylated proteins were removed by the avidin treatment, a substantial proportion of the Fc $\gamma$ R III remained in this fraction, suggesting that it was intracellular (nonbiotinylated) Fc $\gamma$ R III. 
stimulated PMN, we next measured shedding at different FMLP concentrations and durations of exposure. As measured by the $3 \mathrm{G} 8$ binding inhibition assay of PMN supernatants (Fig. 7 , bottom), the amount of Fc $\gamma$ R III released from FMLPstimulated PMN was directly related to the concentrations of FMLP and the duration of exposure to this agent. There was some spontaneous shedding at $37^{\circ} \mathrm{C}$ in the absence of FMLP, which may correspond to the modest gradual decrease in surface Fc $\gamma \mathrm{R}$ III at $37^{\circ} \mathrm{C}$ seen for control PMN in Fig. 1. The very low shedding at $0^{\circ} \mathrm{C}$ here is consistent with data (not shown) indicating steady levels of surface Fc $\gamma \mathrm{R}$ III at $0^{\circ} \mathrm{C}$. Near-maximal FMLP-induced shedding occurred by $60 \mathrm{~min}$, but $45-50 \%$ of this shedding had already occurred by $15 \mathrm{~min}$. In Fig. 7 (top), parallel measurements of the Fc $\gamma$ R III in these PMN supernatants assayed by $3 \mathrm{G} 8$ Western blots gave qualitatively similar results, confirming the time- and concentration-dependent effect of FMLP on Fc $\gamma$ R III shedding from PMN.

Stoichiometric analysis of FMLP-induced changes in PMN surface and intracellular $F c \gamma R$ III. To further examine the relationship between translocation and shedding of Fc $\gamma$ R III and their respective effects on surface expression of this receptor on chemoattractant-stimulated PMN, we performed experiments similar to those described in Fig. 3. In these studies, however, we assessed concurrent quantitative changes in both surface and intracellular Fc $\gamma$ R III over time by using immunofluorescence flow cytometry with FMLP-treated PMN that had been pretreated with or without elastase, as for Fig. 1. Specific 3G8 staining of permeabilized PMN was used as a measurement of total Fc $\gamma$ R III, while parallel staining of nonpermeabilized PMN from the same treatment condition was used to measure surface Fc $\gamma$ R III. The difference between the two values was taken as the value for intracellular $F c \gamma R$ III. As shown in the left panel of Fig. $8 \mathrm{~A}$, there was marked depletion of intracellular Fc $\gamma$ R III after 15 min of FMLP treatment, similar to that shown in Fig. 3. The overall loss of total cellular Fc $\gamma$ R III is consistent with more qualitative assessments of the shedding of this receptor from the cell surface, as described earlier in Fig. 7 and as demonstrated in the $3 \mathrm{G} 8$ blots of supernatants of identically treated PMN depicted in the left panel of Fig. $8 \mathrm{~B}$. The stability of surface levels of Fc $\gamma$ R III can be accounted for by concomitant translocation from intracellular stores. Identical experiments with PMN whose surface Fc $\gamma \mathbf{R}$ III had been removed by pretreatment with elastase (right panel Fig. $8 A$ ) demonstrated the replacement of surface Fc $\gamma R$ III by translocation to the cell surface and that the concomitant depletion of intracellular Fc $\gamma$ R III by FMLP treatment was the same as for non-elastase-treated PMN. There was less FMLPinduced loss of total cellular Fc $\gamma$ R III from elastase-pretreated PMN than from control PMN, consistent with the diminished shedding from elastase-treated PMN shown qualitatively in the $3 \mathrm{G} 8$ blots of cell supernatants in Fig. $8 \mathrm{~B}$. This decrease in the amount of $\mathrm{Fc} \gamma \mathrm{R}$ III shed from the elastase-treated cells is presumably because there was very little surface Fc $\gamma$ R III available for shedding at $t=0 \mathrm{~min}$. Thus it is apparent from this more comprehensive assessment that FMLP-induced translocation and shedding of Fc $\gamma$ R III by normal PMN are concurrent processes that exert opposing effects of comparable magnitude on the surface expression of this PMN receptor.

\section{Discussion}

Neutrophil surface receptors known to be important in phagocytic host defenses and inflammation include the complement receptors, CR1 and CR3, and IgG Fc receptors, especially Fc $\gamma$

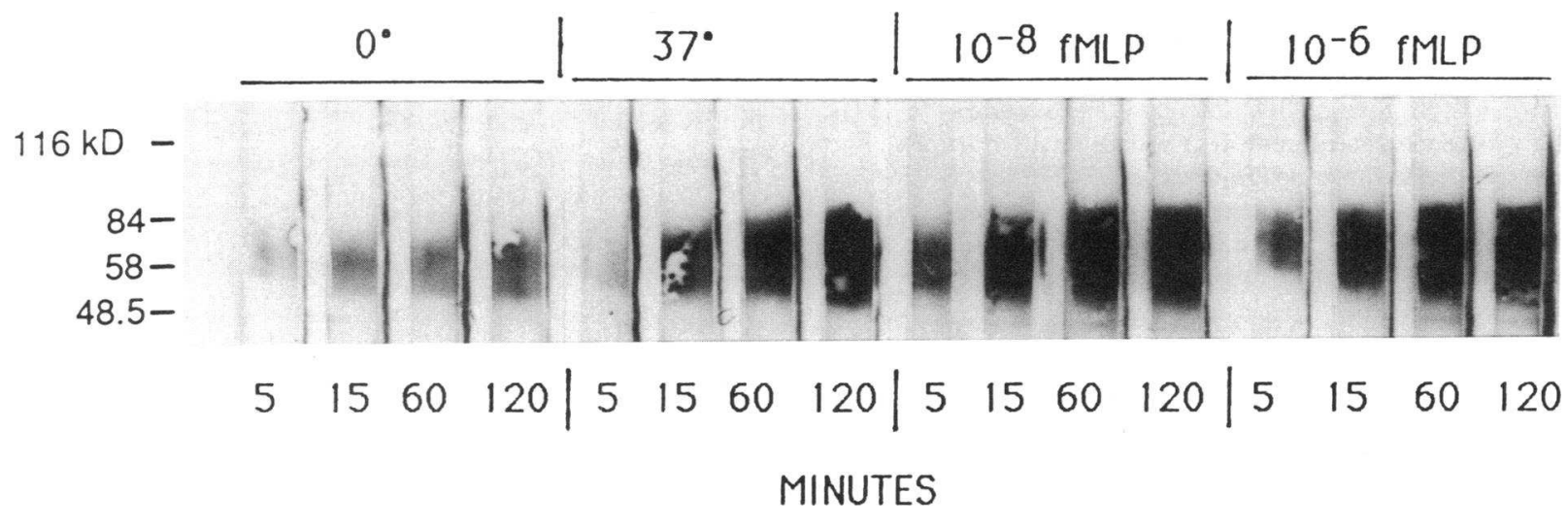

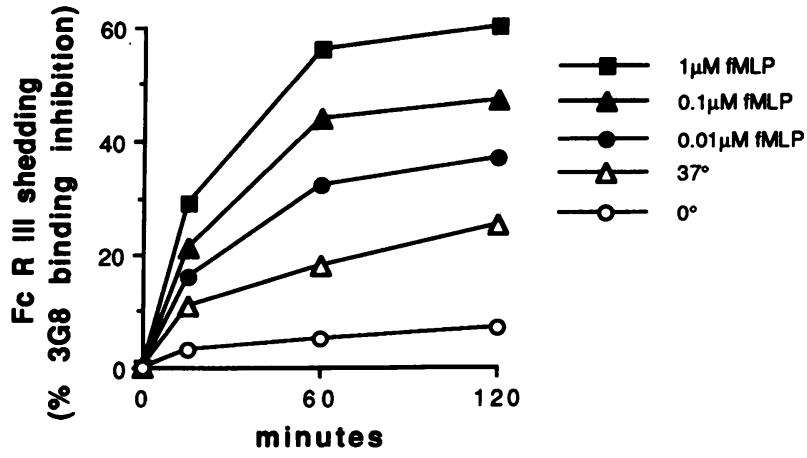

Figure 7. Time and concentration effects of FMLP on shedding of $\mathrm{Fc} \gamma \mathrm{R}$ III from PMN. Suspensions of purified PMN ( $10^{7}$ cells in $0.1 \mathrm{ml}$ PBS) were incubated at $0^{\circ} \mathrm{C}$ or at $37^{\circ} \mathrm{C}$ in the presence of FMLP at varying concentrations for the durations indicated. The supernatants from these cells were collected and analyzed for Fc $\gamma$ R III content by both the 3G8 binding inhibition assay (lower panel) and the 3G8 Western blot assay ( upper panel), as described in Methods. The results shown for binding inhibition assays are representative of five similar experiments with different PMN donors. The Western blot shown is representative of three similar experiments with different donors. 

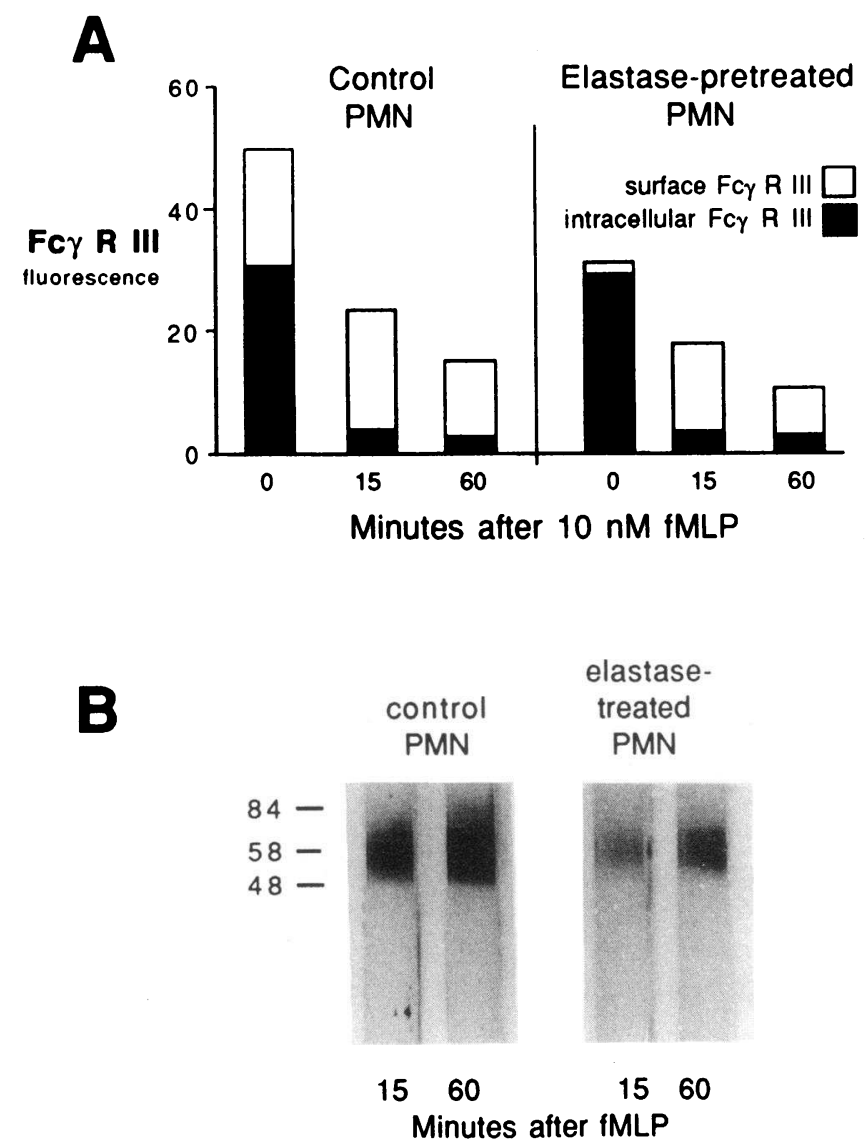

Figure 8. Stoichiometric analysis of the effects of FMLP stimulation of PMN on total, surface, and intracellular Fc $\gamma$ R III. PMN were preincubated either in PBS alone $(A$; left $)$ or $30 \mu \mathrm{g} / \mathrm{ml}$ of elastase $(A$; right) for 30 minutes. Cells were then treated with $10 \mathrm{nM}$ FMLP for the durations indicated. After fixation in paraformaldehyde as described, PMN that been permeabilized with saponin were stained with MAb 3G8 by indirect immunofluorescence to obtain a measurement of total cellular Fc $\gamma$ R III. Specific 3G8 staining of fixed, nonpermeabilized PMN provided a measurement of surface Fc $\gamma$ R III (open portion of bars), which was subtracted from the values for total cell content to determine intracellular content of Fc $\gamma$ R III (dark portion of bars). Thus, the changes over time in intracellular, surface, and total cell Fc $\gamma \mathrm{R}$ III could be evaluated concurrently. In $B$, supernatants from PMN treated as in $A$, were assessed with 3G8 Western blots, to demonstrate differences in FMLP-induced shedding by control vs. elastase-pretreated PMN. The results shown are representative of those for three similar sets of experiments using cells from different donors.

R II and Fc $\gamma$ R III (20-23). Functional and biochemical characteristics of complement and Fc receptors on PMN have been reviewed elsewhere (9-13, 24-28). Earlier studies of CR1 and CR3 on PMN showed that FMLP treatment induced five- to eightfold increases in the expression of these receptors on the cell surface, an effect that arms these cells for enhanced complement-mediated phagocytosis $(1,2)$. However, previously published data, as well as our own current data, indicated that there is little net effect of FMLP or other chemoattractants on PMN surface expression of $F c \gamma$ receptors $(2,6)$.

Recent findings from our own and other laboratories caused us to reevaluate the effects of chemoattractant stimulation on PMN Fc $\gamma$ R III. The demonstration by Huizinga et al.
(9), that FMLP treatment of PMN caused shedding of Fc $\gamma$ R III from the cell surface might, by itself, suggest that there should be an associated reduction in surface Fc $\gamma$ R III. However, as noted above, Fc $\gamma$ R III surface expression generally changed little after FMLP treatment. As further demonstrated by both immunofluorescence ( 7 ) and immunoelectron microscopy (8), there is a large preformed intracellular store of $\mathrm{Fc} \gamma \mathrm{R}$ III in PMN. In fact, since some translocation of membrane proteins may occur during cell purification, estimates of intracellular pools in isolated PMN may be slightly lower than is actually the case, in vivo. Taken together with the FMLP-induced shedding of this receptor in the face of stable surface expression, this led us to hypothesize that FMLP stimulation of PMN induced a rapid translocation of $\mathrm{Fc} \gamma \mathrm{R}$ III from preformed intracellular stores to the cell surface. The resulting appearance of large amounts of new Fc $\gamma$ R III on the PMN surface could not be detected by examining changes in surface expression alone, as has been achieved with CR1 and CR3, presumably because the concomitant shedding of $\mathrm{Fc} \gamma \mathrm{R}$ III roughly counterbalanced, and thus masked, the proposed FMLP-induced translocation. After elastase or PIPLC pretreatment of PMN to remove $90 \%$ of the Fc $\gamma$ R III $(9,10)$, we were able to demonstrate the FMLP-induced renewal of $\mathrm{Fc} \gamma \mathbf{R}$ III on the PMN surface, to $\sim 70 \%$ of the original levels (Fig. 1), consistent with translocation of this receptor from intracellular stores to the cell surface. This effect of FMLP was rapid and concentration dependent (maximal at $15 \mathrm{~min}, 10 \mathrm{nM}$ FMLP) and independent of extracellular calcium. Thus, the removal of surface $\mathrm{Fc} \gamma \mathrm{R}$ III before FMLP treatment of PMN unmasked the translocation of new Fc $\gamma$ R III to the surface, presumably by minimizing shedding as an opposing influence on surface expression.

To confirm that the appearance of new surface $\mathrm{Fc} \gamma \mathrm{R}$ III on PMN was the result of FMLP-induced translocation from intracellular sites, we measured the specific $F c \gamma$ R III immunofluorescence of permeabilized PMN after FMLP treatment of PMN and demonstrated the depletion of $>80 \%$ of the intracellular Fc $\gamma$ R III by 15 min (Fig. 3). This depletion occurred whether or not $\mathrm{Fc} \gamma \mathrm{R}$ III was first removed by pretreatment with elastase (Fig. 8). Thus, we concluded that intracellular Fc $\gamma$ R III was the source of newly expressed surface Fc $\gamma$ R III on FMLP-treated PMN.

The sites of intracellular storage of Fc $\gamma$ R III in PMN have not been fully defined. In PMN cavitates subjected to discontinuous Percoll density gradient fractionation, $\mathrm{Fc} \gamma \mathrm{R}$ III was most prominent in the peak alkaline phosphatase-containing fraction, with a second, smaller peak at a density similar to the specific granule or lactoferrin-containing fractions (Fig. 5). The former includes plasma membrane, but also a substantial component of alkaline phosphatase-containing membrane that is intracellular but which sediments at a density very close to that of plasma membranes $(18,19)$. Our studies with surface-biotinylated PMN showed that, while a sizable portion of the Fc $\gamma$ R III in the alkaline phosphatase peak fractions must be from the plasma membrane, some of this Fc $\gamma$ R III was present at intracellular sites. It may be pertinent that the latent alkaline phosphatase-containing vesicles described by Borregaard et al. $(18,19)$, the vesicular intracellular storage sites for CR1 described by Berger et al. (29), and the small intracellular vesicles containing Fc $\gamma$ R III described by Jost et al. (8), all have similar morphology in PMN studied by electron microscopy; it has been speculated that these molecules may be stored 
in the same or very similar intracellular sites (29). The signifcance of the apparent heterogeneity of intracellular Fc $\gamma$ R III in PMN and the extent to which each intracellular pool contributes to FMLP-stimulated translocation have not been determined. Further studies are necessary to define more precisely the nature of these intracellular compartment(s) and to determine the significance of their heterogeneity.

Ligand-independent internalization of $\mathrm{Fc} \gamma \mathrm{R}$ III, as has been described for CR1 (7), either is not induced by FMLP or is otherwise of very small magnitude in comparison to translocation or shedding. This conclusion is based largely on our inability to detect FMLP-induced internalization of surfacebound biotinylated monovalent Fab of 3G8 (Tosi, unpublished data).

Comparisons of various aspects of shedding vs. translocation indicated that $(a)$ translocation was maximal at $10 \mathrm{nM}$ FMLP, whereas shedding continued to increase with higher FMLP concentrations, up to $1 \mu \mathrm{M}$, the highest concentration tested; $(b)$ translocation was virtually complete by $15 \mathrm{~min}$, whereas shedding continued for at least $60 \mathrm{~min} ;(c) 5 \mathrm{mM}$ EDTA did not affect translocation, although it has been shown to inhibit shedding (Tosi, unpublished data; 30 ); and $(d)$ the release of Fc $\gamma$ R III from FMLP-treated PMN is greatly reduced, especially at earlier time points, if surface Fc $\gamma$ R III is first removed by elastase and PIPLC, even though translocation is unchanged (Fig. $8 \mathrm{~B}$ ). These findings indicated that translocation and release of $\mathrm{Fc} \gamma \mathrm{R}$ III may occur concomitantly in FMLP-treated PMN but are separately regulated processes. Taken together with studies of PMN cytoplasts by Huizinga et al. (30), these comparisons also provide strong evidence that cell surface $\mathrm{Fc} \gamma \mathrm{R}$ III is the source of any Fc $\gamma$ R III released upon FMLP stimulation, that direct secretion of unanchored intracellular Fc $\gamma$ R III is an unlikely alternative mechanism, and that $\mathrm{Fc} \gamma \mathrm{R}$ III newly translocated to the PMN surface is itself subject to the shedding process.

Although the function of Fc $\gamma$ R III on the PMN surface is at least partly understood $(10,22-25)$, the biologic role of shed Fc $\gamma$ R III is unknown. One possibility is that the released receptor may serve to down-modulate cellular responses to IgG complexes in inflammatory states by binding these complexes away from the cell surface. Huizinga et al. (30) demonstrated that soluble $\mathrm{Fc} \gamma \mathrm{R}$ III in human plasma or serum is associated with monomeric IgG. It is not clear, however, whether this association occurs before or after the receptor is released from the PMN surface. In contrast to the ability of shed Fc $\gamma$ R III in our studies to specifically inhibit binding of 3G8 MAb to PMN, activated PMN supernatants containing the greatest amounts of shed Fc $\gamma$ R III fail to inhibit the binding of multivalent IgG complexes to freshly isolated PMN (Tosi, unpublished data). Thus, the potential interactions of shed Fc $\gamma$ R III with IgG remain to be fully characterized.

Our studies show that the effects of FMLP on the movement of Fc $\gamma$ R III in PMN are complex, and involve the stimulation of rapid translocation of one or more preformed intracellular membrane storage pools of Fc $\gamma$ R III to the PMN surface with the concomitant shedding of surface $\mathrm{Fc} \gamma \mathrm{R}$ III into the extracellular milieu. The simultaneous translocation and shedding of $\mathrm{Fc} \gamma \mathrm{R}$ III, while regulated by distinct mechanisms, together serve to maintain the surface expression of Fc $\gamma$ R III at relatively constant levels, during chemoattractant stimulation of PMN, at least until intracellular Fc $\gamma$ R III is depleted. Further studies aimed at more precisely defining its intracellular storage compartments, the molecular mechanisms of its translocation and shedding, and biologic functions of both cell-surface and released Fc $\gamma$ R III will advance the effort to understand more fully the role of this PMN receptor in infectious and inflammatory diseases.

\section{Acknowledgments}

The authors wish to thank Drs. Melvin Berger and Alan Tartakoff for their critical comments and helpful suggestions.

These studies were supported in part by grants from the U.S. Public Health Service (HL-02234) and the Cystic Fibrosis Foundation.

\section{References}

1. Fearon, D. T., and L. A. Collins. 1983. Increased expression of C3b receptors on polymorphonuclear leukocytes induced by chemotactic factors and by purification procedures. J. Immunol. 130:370-375.

2. Berger, M., J. O'Shea, A. S. Cross, T. M. Folks, T. L. Chused, E. J. Brown, and M. M. Frank. 1984. Human neutrophils increase expression of C3bi as well as C3b receptors upon activation. J. Clin. Invest. 74:1566-1571.

3. Fletcher, M. P., and J. I. Gallin. 1980. Degranulation stimuli increase the availability of receptors in human neutrophils for the chemoattractant f-MetLeu-Phe. J. Immunol. 124:1585-1588.

4. Berger, M., and M. E. Medof. 1987. Increased expression of complement decay-accelerating factor during activation of human neutrophils. J. Clin. Invest. 79:214-220.

5. Borregaard, N., J. M. Heiple, E. R. Simons, and R. A. Clark. 1983. Subcellular localization of the b-cytochrome component of the human neutrophil microbicidal oxidase: translocation during activation. J. Cell Biol. 97:52-61.

6. Miller, L. J., D. F. Bainton, N. Borregaard, and T. A. Springer. 1987. Stimulated mobilization of monocyte mac-1 and p1 50,95 adhesion proteins from an intracellular vesicular compartment to the cell surface. J. Clin. Invest. 80:534544.

7. Turner, J. R., A. M. Tartakoff, and M. Berger. 1988. Intracellular degradation of the complement $\mathrm{C} 3 \mathrm{~b} / \mathrm{C} 4 \mathrm{~b}$ receptor in the absence of ligand. J. Biol. Chem. 263:4914-4920.

8. Jost, C. R., T. Huizinga, R. DeGoede, F. A. M. Fransen, P. A. T. Tetteroo, M. R. Daha, and L. A. Ginsel. 1990. Intracellular localization and de novo synthesis of Fc $\gamma$ R III in human neutrophil granulocytes. Blood. 75:144-151.

9. Huizinga, T. W. J., C. E. van der Schoot, C. Jost, R. Klaassen, M. Kleijer, A. E. G. Kr. von dem Borne, D. Roos, and P. A. T. Tetteroo. 1988. The PI-linked receptor Fc $\gamma$ R III is released on stimulation of neutrophils. Nature (Lond.). 333:667-669.

10. Tosi, M., and M. Berger. 1988. Functional differences between the $40 \mathrm{kDa}$ and 50 to $70 \mathrm{kDa}$ IgG Fc $\gamma$ receptors on human neutrophils revealed by elastase treatment and antireceptor antibodies. J. Immunol. 141:2097-2103.

11. Tosi, M. F., and M. R. Hammerschlag. 1988. Chlamydia trachomatis selectively stimulates myeloperoxidase release but not superoxide production by human neutrophils. J. Infect. Dis. 158:457-460.

12. Borregaard, N., and A. I. Tauber. 1984. Subcellular localization of the human neutrophil microbicidal oxidase: translocation during activation. J. Cell Biol. 97:53-61.

13. Hetherington, S. V., J. K. Spitznagel, and P. G. Quie. 1983. An enzymelinked immunoassay (ELISA) for measurement of lactoferrin. J. Immunol. Methods. 65:183-1900.

14. Henson, P. M., B. Zanolar, N. A. Schwartzman, and S. R. Hong. 1978. Intracellular control of human neutrophil secretion. I. C5a-induced stimulus-specific desensitization and the effects of cytochalasin B. J. Immunol. 121:851-855.

15. Laemmli, U. K. 1970. Cleavage of structural proteins during the assembly of the head of bacteriophage T4. Nature (Lond.). 227:678-685.

16. Towbin, H., T. Staehelin, and J. Gordon. 1979. Electrophoretic transfer of proteins from polyacrylamide gels to nitrocellulose sheets: procedure and some applications. Proc. Natl. Acad. Sci. USA. 76:4350-4354.

17. Goodloe-Holland, C. M., and E. J. Luna. 1987. Purification and characterization of Dictyostelium discoideum plasma membranes. Methods Enzymol. 28:103-125.

18. Borregaard, N., L. J. Miller, and T. A. Springer. 1987. Chemoattractantregulated mobilization of a novel intracellular compartment in human neutrophils. Science (Wash. DC). 237:1204-1206.

19. Borregaard, N., L. Christensen, O. W. Bjerrum, H. S. Birgens, and I. Clemmensen. 1990. Identification of a highly mobilizable subset of human neutrophil intracellular vesicles that contains tetranectin and latent alkaline phosphatase. J. Clin. Invest. 85:408-416. 
20. Unkeless, J. C., and S. D. Wright. 1984. Structure and modulation of Fcy and complement receptors. Contemp. Top. Immunobiol. 14:171-187.

21. Berger, M., T. A. Gaither, and M. M. Frank. 1983. Complement receptors. Clin. Immunol. Rev. 1:4711-4745.

22. Anderson, C. L., and R. J. Looney. 1986. Human leukocyte IgG Fcy receptors. Immunol. Today. 7:264-269.

23. Unkeless, J. C. 1989. Function and heterogeneity of human $\mathrm{Fc} \gamma$ receptors for immunoglobulin G. J. Clin. Invest. 83:355-361.

24. Salmon, J. E., S. Kapur, and R. P. Kimberly. 1987. Opsonin-independent ligation of $\mathrm{Fc} \gamma$ receptors; the 3G8-bearing receptors on neutrophils mediate the phagocytosis of concanavalin A-treated erythrocytes and non-opsonized $E$. coli. J. Exp. Med. 166:1798-1813.

25. Salmon, J. E., J. C. Edberg, and R. P. Kimberly. 1990. Fc $\gamma$ receptor III on human neutrophils: allelic variants have functionally distinct capacities. J. Clin. Invest. 85:1287-1295.
26. Perussia, B., E. Dayton, R. Lazarus, V. Fanning, and G. Trinchieri. 1985. Immune interferon induces the receptor for monomeric IgGl on human monocyte and myeloid cells. J. Exp. Med. 158:1092-1113.

27. Fanger, M. W., L. Shen, R. F. Graziano, and P. M. Guyre. 1989. Cytotoxicity mediated by human Fc $\gamma$ receptors for IgG. Immunol. Today. 10:92-99.

28. Guyre, P. M., S. A. Campbell, W. D. Kniffin, and M. W. Fanger. 1990. Monocytes and polymorphonuclear neutrophils of patients with streptococcal pharyngitis express increased numbers of type I IgG Fc receptors. J. Clin. Invest. 86:1892-1896.

29. Berger, M., E. M. Wetzler, E. Welter, J. Turner, and A. M. Tartakoff. 1989. Intracellular sites for storage and recycling of $\mathrm{C} 3 \mathrm{~b}$ receptors in human neutrophils. Proc. Natl. Acad. Sci. USA. 88:3019-3023.

30. Huizinga, T. W. J., M. de Haas, M. Kleijer, J. H. Nuijens, and A. E. G. von dem Borne. 1990. Soluble Fc $\gamma$ receptor III in human plasma originates from release by neutrophils. J. Clin. Invest. 86:416-423. 